\title{
INSIDE OUTSIDE CYRCLE: METODE PEMBELAJARAN UNTUK MENGEMBANGKAN KEMAMPUAN BERBICARA ANAK
}

\author{
Baiq Shofa Ilhami ${ }^{1}$, Muhammad Husni ${ }^{2}$, Sandy Ramdhani ${ }^{3}$, Nurul Uyun ${ }^{4}$ \\ Fakultas Ilmu Pendidikan Universitas Hamzanwadi \\ Email: shofa.ilhami@gmail.com ${ }^{1}$, muhammad.husni2014gmail.com², sandy160392@gmai.com ${ }^{3}$, \\ nurul.uyun20@gmail.com ${ }^{4}$. \\ Ilham, Baiq Shofa. (2020). Inside Outside Cyrcle: Metode Pembelajaran Untuk Mengembangkan \\ Kemampuan Berbicara Anak Usia 5-6 Tahun. Jurnal Pelita PAUD, 4(2), 247-253. \\ doi: https://doi.org/10.33222/pelitapaud.v4i1.1001
}

\begin{abstract}
Abstrak: Aspek perkembangan Bahasa dan literasi khususnya kemampuan berbicara pada anak usia 5-6 tahun merupakan satu aspek yang menjadi perhatian khusus dalam perkembangan anak. metode yang digunakan untuk meningkatkan aspek kemampuan berbicara adalah metode inside outside learning. Penelitian yang digunakan adalah penelitian kuantitatif dengan menggunakan jenis penelitian eksperimen dengan Teknik analisis data menggunakan paired sampel t-test. Perkembangan Bahasa dan literasi khususnya kemampuan berbicara dengan menggunakan metode inside outside circle didapatkan hasil uji " $\mathrm{t}$ " (Paired $T$-Sample) ternyata $\mathrm{t}_{\text {hitung }} \geq \mathrm{t}_{\text {tabel }}(5,147>1,706)$. Perkembangan kemampuan berbicara yang berkembang dengan menggunakan metode inside outside cyrcle diantaranya kemampuan intonasi Bahasa, kemampuan komunikasi, penguasaan kata-kata sederhana, dan meningkatnya kemampuan menyusun kalimat sederhana

Kata kunci : Bahasa; literasi; kemampuan berbicara; inside outside learning;

Abstract: Aspects of language development and literacy, especially the ability to speak in children aged 5-6 years is one aspect of special concern in child development. the method used to improve aspects of language development and children's literacy, especially speaking skills, is the method inside outside learning. The research used is quantitative research using experimental research types with data analysis techniques using paired sample t-test. Language development and literacy, especially the ability to speak using the method inside the outside circle, obtained the results of the " $t$ " (Paired T-Sample) test turned out to be t-count t table (5.147> 1.706). Language development and literacy, especially the ability to speak that develops using the method outside the cyrcle, including the ability of language intonation, communication skills, mastery of simple words, and increased ability to compose simple.
\end{abstract}

Keywords: there or more word(s) or phrase(s), that it's important, spesific, or representative for the article.

(C) 2020 Baiq Shofa Ilhami ${ }^{1}$, Muhammad Husni $^{2}$, Sandy Ramdhani ${ }^{3}$, Nurul Uyun ${ }^{4}$ Under the license CC BY-SA 4.0

http://jurnal.upmk.ac.id/index.php/pelitapaud 


\section{PENDAHULUAN}

Bahasa merupakan alat untuk berpikir, mengekspresikan diri dan berkomunikasi. Keterampilan berbahasa juga penting dalam rangka pembentukan konsep, informasi, dan pemecahan masalah. Melalui bahasa pula anak dapat memahami komunikasi pikiran dan perasaan. Bahasa adalah suatu urutan kata-kata, bahasa juga dapat digunakan untuk menyampaikan informasi mengenai tempat yang berbeda atau waktu yang berbeda(Ilhami et al., 2019; Nahdi \& Yunitasari, 2019). Bahasa sebagai alat komunikasi, menjadi sarana yang sangat penting dalam kehidupan anak. Minat anak pada usia dini sangat luas dan selalu ingin mengetahui segala sesuatu yang ada disekitarnya. Anak adalah makhluk peniru (imitator), anak mencontoh orangorang yang ada di sekelilingnya ketika melihat sesuatu yang baru dilihat oleh anak, karena pada masa ini anak-anak memiliki rasa tahu yang tinggi dan dorongan untuk meniru orang lain sangat kuat sehingga kemampuan imitasi anak menjadi modal penting dalam perkembangan bahasanya(Nahdi \& Yunitasari, 2020; Palupi, 2015; Ramdhani et al., 2019).

Perkembangan bahasa anak sejalan dengan rasa ingin tahu serta sikap antusias yang tinggi, sehingga timbul pertanyaan-pertanyaan dari anak dengan kemampuan bahasanya. Perkembangan bahasa anak antara usia 4 dan 5 tahun, kalimat anak sudah terdiri dari empat sampai lima kata.Perkembangan bahasa anak antara usia 5 dan 6 tahun, kalimat anak sudah terdiri dari enam sampai delapan kata. Anak sudah dapat menjelaskan arti kata-kata yang sederhana (Agustina \& Hafidz, 2018; Nuraeni, 2016; Pertiwi et al., 2017) Pada dasarnya di dalam mempelajari perkembangan bahasa maka semakin tinggi penguasaan bahasa anak maka semakin baik pula kemampuan berbicara anak dalam berkomunikasi. Berbicara bukanlah sekedar pengucapan kata atau bunyi, tetapi merupakan suatu alat untuk mengekspresikan diri, menyatakan, menyampaikan, atau mengomunikasikan pikiran, ide, maupun perasaan. Berbicara merupakan suatu keterampilan berbahasa yang berkembang dan dipengaruhi oleh keterampilan menyimak. Kemampuan berbicara berkaitan dengan kosakata yang diperoleh anak dari kegiatan menyimak dan membaca(Inten, 2017; Ramdhani et al., 2019.; Sumaryanti, 2018).

Salah satu aspek kemampuan berbahasa dan literasi anak usia dini yag terpenting adalah kemampuan berbicara kemampuan berbahasa terutama kemampuan berbicara anak usia dini menjadi sebuah aspek perkembangan Bahasa yang menjadi sebuah hal pokok yang harus dikembangkan dalam proses perkembangan anak misalkan saja dalam menyebutkan nama, berkomunikasi dengan teman sebaya dan juga dengan guru. Kemampuan berbicara terutama dalam proses artikulasi dan kejelasan kata anak menjadi keterhambatan yang paling dominan dalam sebuah perkembangan Bahasa anak terutama kemampuan berbicaranya. (Adams-Chapman et al., 2015; Holod et al., 2018; Sudrajad \& Wijaya, 2016).

Salah satu metode yang bisa menjadi solusi dalam mengembangkan kemampuan berbahasa dan literasi anak usia dini terutama kemampuan berbicaranya adalah dengan menggunakan sebuah metode yang bernama Inside Outside Cyrcle. Metode Inside Outside Cyrcle merupakan metode pembelajaran yang informatif dan menfokuskan kepada anak untuk mencari pengetahuan secara mandiri dan mampu mengakses informasi serta mengolah informasi. Metode Inside outside cyrcle merupakan metode yang dijelaskan sebagai sebuah lingkaran (Marceillina et al., 2019; Muyaroah, 2018; Nahdi \& Yunitasari, 2019; Sudrajad \& Wijaya, 2016). Metode inside-outside-circle bertujuan memberikan kesempatan pada anak untuk terlibat secara aktif dalam proses berfikir, mandiri dan melatih anak untuk berbicara, menyampaikan informasi kepada orang lain serta anak secara luas mengemukakan pendapatnya.

Metode inside-outside Cyrcle merupakan mengembangan dari model pembelajaran koperatif yang mengedepankan tentang pentingnya proses pembelajaran dilaksanakan dengan adanya tim dalam setiap pelaksanaan kegiatannya. Metode inside-outside cyrcle memberikan kesempatan kepada anak-anak saling berbagi dengan teman lainnya. proses komunikasi dan saling membantu dalam proses pembelajaran membuat anak dapat memberikan sebuah arah dalam penerapan proses pembelajaran metode inside outside 
Vol. 4 No. 2 Juni 2020

cyrcle memiliki kelebihan terutama dalam meningkatkan kemampuan berbahasa anak (Madra, 2019; Marceillina et al., 2019; Wijaya, 2017).

Aspek perkembangan Bahasa dan literasi khususnya kemampuan berbicara anak usia dini terutama usia 5-6 tahun sudah mengarah kepada pengaplikasian pembelajaran untuk mencapai tingkat berikutnya. Kemampuan berbicara anak usia 5-6 tahun ditandai dengan kemampuan menguasai penyusunan kata menjadi kalimat sederhana, mampu menjawab pertanyaan tentang kejadian-kejadian di sekitar, mampu mengulang kalimat-kalimat yang terdiri dari 6-8 kata, menguasai berbagai nama benda di sekitar dan mampu untuk menceritakan pengalaman dengan sederhana ((Brown, 2014; Ilhami et al., 2019; Marsh, 2008; Nahdi \& Yunitasari, 2019; Ramírez et al., 2013; Toki \& Pange, 2014). Berbicara mencangkup tiga proses terpisah tetapi saling berbubungan satu sama lain, yakni belajar mengucapkan kata, membentuk kalimat dan membangun kosakata (Bornstein et al., 2014; Jalongo, 2018) Penerapan metode insideoutside cyrcle dalam mengembangkan aspek Bahasa dan literasi terutama kemampuan berbicara anak membutuhkan bantuan dari media-media dan alat permainan edukatif ketika proses pembelajaran berlangsung. Media-media pembelajaran tersebut sebagai alat pendukung untuk menstimulasi perkembangan Bahasa dan literasi anak. diantara media-media yang digunakan sebagai alat untuk pemberian stimulus bagi perkembangan anak terutama anak usia 6 tahun adalah media gambar, kartu kata, dan flipchart ((Aged, 2015; Kim, 2014; Marsh, 2008; Valdebenito et al., 2017)

\section{METODE PENELITIAN}

Penelitian yang digunakan adalah penelitian kuantitatif dengan menggunakan penelitian kuantitatif eksperimen. desain penelitian yang digunakan adalah Quasi Experimental Design dengan jenis Nonequivalent Control Group Design ((Model et al., 2016). populasi yang digunakan adalah 40 anak terdiri dari 2 kelas kelompok B dengan usia 5-6 tahun di Ummi Adniyah NW Sanggeng dengan pengambilan sampel menggunakan jenis random sampling dengan menggunakan 1 kelas eksperimen dengan jumlah anak 20 orang dan 1 kelas control dengan jumlah anak 20 orang. Teknik pengumpulan data yang digunakan adalah Teknik observasi dan tes untuk melihat aspek kemampuan berbicara anak, wawancara untuk melihat sejauh mana efektivitas metode yang diterapkan dalam proses pembelajaran, dan menggunakan observasi sebagai salah satu cara mengumpulkan data tambahan agar hasil observasi yang akan didapatkan bisa maksimal untuk diperoleh. Sedangkan instrument yang digunakan adalah lembar observasi yang terdiri dari 15 butir pernyataan untuk diobservasi yang dirincikan menjadi keterampilan kemampuan kosakata, kelancaran berbicara, penyusunan kalimat sederhana dari beberapa kata, mampu menyebutkan benda benda disekitar, kemampuan berkomunikasi dan artikulasi berbahasa anak yang didukung dengan tes sebanyak 10 pertanyaan. instrument lain yang digunakan adalah dengan menggunakan pedoman wawancara untuk melihat dampak dari metode Inside-Outside Cyrcle.

Teknik analisis data yang digunakan untuk melihat sejauh Data yang diperoleh selama proses pembelajaran akan dianalisis data observasi dalam persentase dengan menggunakan uji presentasi perkembangan(Nafiah, 2016; Paramita \& Sutapa, 2019). Analisis uji hipotesis pertama dalam penelitian ini menggunakan uji-t (Paired Sampel T-test) dengan Kriteria yang digunakan untuk menguji hipotesis yakni dengan taraf signifikansi $\alpha=0,05$ (Nahdi \& Yunitasari, 2019; Syahrum \& Salim, 2012).

\section{HASIL PENELITIAN \\ DAN PEMBAHASAN}

\section{Hasil Penelitian}

Hasil observasi peneliti dan observer untuk aspek perkembangan bahasa khususnya pada kemampuan berbicara anak didapatkan dari rata-rata persentase keseluruhan anak di kelompok eskperimen yang berjumlah 27 anak dalam penilaian pretest dapat dikategorikan dalam persentase kategori penilaian ialah "Mulai Berkembang" (MB) yang berkisar antara 25\% - 50\%. Penliaian ini belum mencapai tujuan yang diharapkan didasari dengan banyak masalah yang terjadi di lapangan. Terutama dalam proses pembelajaran masih menggunakan cara-cara biasa atau konvensional yaitu pembelajarannya lebih kepada 
ceramah,menulis,membaca berhitung, dan pembelajaran yang menekankan pada interaksi satu arah.

Hasil sesudah penelitian atau posttest didapatkan dari rata-rata persentase keberhasilan kemampuan berbicara anak khususnya pada kelompok eskperimen yang berjumlah 27 anak mendapatkan nilai rata-rata persentase keberhasilan sebesar $70 \%$ dikategorikan dalam persentase kategori penilaian ialah "Berkembang Sesuai Harapan" (BSH). Sedangkan di kelompok kontrol mendapatkan nilai rata-rata pretest sebesar $32 \%$ dan nilai rata-rata persentase keberhasilan anak untuk posttest sebesar $60 \%$ dalam persentase kategori penilaian "Berkembang Sesuai Harapan" (BSH).

Berdasarkan hal di atas dapat disimpulkan bahwa pembelajaran yang menggunakan model inside-outside-circle memberikan pengaruh yang cukup baik daripada pembelajaran tanpa menggunakan model pembelajaran inside-ooutside-circle. Hal ini dapat ditujukan pada hasil nilai rata-rata posttest lebih tinggi yaitu sebesar 70\%, sedangkan rata-rata posttest untuk kelas kontrol sebesar $60 \%$.

Selanjutnya, hasil uji normalitas dari kedua kelas tersebut berada pada kategori "Berdistribusi Normal". Uji normalitas data dilakukan untuk menguji apakah skor dalam variabel yang diteliti distribusi normal atau tidak. Pada normalitas data peneliti menggunakan rumus- chi-kuadrat $\left(\mathrm{x}^{2}\right)$. Dalam perhitungan kedua kelas tersebut ditemukan Chi kuardrat hitung pada kelompok eksperimen $=-173,92$ selanjutnya nilai ini dibandingkan dengan $C h i$ kuadrat tabel= 38,885 , karena $-173,92 \leq 38,885$, maka data dinyatakan "Berdistribusi Normal". Sedangkan pada kelompok kontrol ditemukan Chi kuadrat hitung $=-22,88$ dan nilai $C h i$ kuadrat $_{\text {tabel }}=21,026$, karena $-22,88 \leq 21,026$ maka data dinyatakan "Berdistribusi Normal". Setelah data dinyatakan normal, maka dilanjutkan pada perhitungan uji homogenitas. Hasil dari uji homgenitas kedua kelas tersebut dinyatakan homogen dengan ${ }_{\text {kriteria }}{ }_{F}$ hitung ${ }^{<} F$ tabel. $(1,19 \leq 4,24)$. Selain itu,dalam penelitian ini juga menggunakan uji hipotesis. Hasil dari uji perhitungan uji hipotesis yang diperoleh dengan uji " $\mathrm{t}$ "
(Paired T-Sample) ternyata $\mathrm{t}_{\text {hitung }} \geq \mathrm{t}_{\text {tabel }}(5,147$ $>1,706)$, dengan dmikian dapat disimpulkan

\section{Pembahasan}

Kemampuan berbicara anak dapat dioptimalkan menggunakann kegiatan dan pembelajaran yang sesuai dengan anak dan sesuai dengan aspek perkembangan yang dikembangkan. Pada penelitian ini, pembelajaran kooperatif tipe inside-outsidecircle dapat membantu anak untuk melatih kemampuan berbicaranya dengan cara bercerita secara singkat pada waktu yang bersamaan dengan pasangan menggunakan lingkaran dalam dan lingkaran luar.

Salah satu keunggulan dari model pembelajaran inside-outside-circle yaitu adanya setruktur yang jelas dan memungkinkan siswa untuk saling berbagi informasi dengan singkat dan teratur. Selain itu, siswa memiliki banyak kesempatan untuk mengolah informasi dan meningkatkan keterampilan berkomunikasi. Pada prakteknya, kegiatan ini dapat melatih kemampuan berbicara anak dengan kegiatan bercerita. Anak mendapatkan pengalaman secara langsung karena anak mendapatkan kesempatan untuk mempraktekkan sehingga anak memperoleh kepuasan belajar dan anak juga dapat mengingat informasi yang telah diberikan. Selain itu, sesuai dengan teori Hurluck mengemukakan bahwa faktor yang dapat mempengaruhi kemampuan berbicara anak salah satunya adalah kesiapan untuk berpraktek.

Berdasarkan penelitian yang dilakukan oleh Nur Ardisti \& Endang Purbaningrum (2015) dengan judul "Pengaruh model pembelajaran kooperatif tipe inside-outside-circle terhadap kemampuan berbicara pada anak pada kelompok A di TK Nusa indah Desa Cinandang ". Hasil penelitian tersebut menunjukkan kemampuan berbicara anak saat pretest dan posttest. Rata-rata hasil kemampuan berbicara anak pada pretest yaitu 7,3, sedangkan rata-rata hasil kemampuan berbicara anak pada posttest yaitu 14,4. Hal tersebut menunjukkan bahwa kemampuan berbicara anak pada pretest lebih rendah dibandingkan dengan kemampuan berbicara anak saat posttest, sehingga menunjukkan adanya perubahan hasil kemampuan berbicara anak sebelum dan 
P ISSN 2548-6284 E ISSN 2615-0360

Vol. 4 No. 2 Juni 2020

sesudah diberikan perlakuan dengan menggunakan pembelajaran kooperatif tipe inside-outside-circle.

Hasil penelitian lain yang dilakukan oleh Misiah, Hasan Mahfud \& Anayati Rahmawati (2014) dengan judul"Meningkatkan Keterampilan Berbicra Anak Usia Dini Melalui Model Pembelajaran Kooperatif Tipe Inside-Outside-Cirle Pada Kelompok A TK Marsudiswi Jajar". Penelitian ini menggunakan siklus, tindakan dalam penelitian ini dilakukan sebanyak dua siklus. Hasil nilai pada siklus 1 belum mencapai terget, hanya $61,5 \%$ atau 8 anak dari 13 anak yang mencapai ketuntasan, disebabkan karena belum mencapai target maka perlu dilaksanakan siklus II. Pada siklus II indikator yang sama, hasil nilai keterampilan berbicara anak meningkat mencapai $84,6 \%$ atau 11 anak dari 13 anak yang mencapai ketuntasan. Hal ini menunjukkan bahwa penerapan model pembelajaran kooperatif tipe inside-outsidecircle dapat meningkatkan keterampilan berbicara anak pada kelompok A di TK Marsudisiwi Jajar Tahun pelajaran 2013/2014

Berdasarkan hasil penelitian tersebut dengan judul yang sama dan hasil dari penelitian ini dengan menggunakan teknik analisis data yang digunakan dapat memberikan jawaban bahwa dengan menerapkan model pembelajaran inside-outside-circle memberikan pengaruh yang baik terhadap kemampuan berbicara anak. Hal ini juga, pada pelaksanaan perlakuan dengan menggunakan model pembelajaran inside-outside- saat proses kegiatan pembelajaran awal berdampak positif, anak belajar menemukan hal yang baru, belajar secara langsung dan memberikan kesempatan kepada anak untuk menarik pernyataan dan pertanyaan yang muncul dalam pikirannya.

\section{SIMPULAN}

Berdasarkan hasil yang terkumpul sebelum dilakukan perlakuan atau pretest diperoleh total jumlah kemampuan berbicara keseluruhan anak yaitu 691, pada persentase kategori penilaian diperoleh nilai rata-rata persentase keseluruhan yakn $35(\%)$ dengan kategori penilaian Mulai Berkembang” (MB) dan setelah dilaksanakan penelitian atau posttest diperoleh total jumlah kemampuan berbicara keseluruhan anak yaitu 1324, pada persentase kategori penilaian diperoleh nilai rata-rata persentase keseluruhan yakni 70 (\%) dari keseluruhan 27 anak dengan kategori penilaian berkembang sesuai harapan (BSH), sedangkanpada kelas kontrol diperoleh ratarata persentase pada tahap pretest sebesar $32 \%$ dan posttets sebesar $60 \%$ ketegori penilaian dari kedua kelas tersebut dalam kategori "Berkembang Sesuai Harapan" meski kedua kelas tersebut berada pada kategori penilaian yang sama namun, terdapat perbedaan pada nilai posttest eksprimen dan kontrol $70 \% \geq 60 \%$, ini menunjukkan bahwa terdapat perbedaan hasil pembelajaran di kelas eskprimen (kelas menggunakan model pembelajaran inside-outside-circle) dengan kelas kontrol (tanpa menggunakan model pembelajaran inside-outside-cirle). Penerapan model pembelajaran inside-outside-circle memberikan terobosan baru dalam proses pembelajaran, dimana anak diberikan kesempatan untuk menjelaskan materi pelajaran kepada temannya dengan bahasanya sendiri sesuai pemahamannya masing-masing. Pada proses pembelajaran kegiatan awal hingga akhir, tahapan apersepsi, membuat lingkaran,mencari pasangan sampai pada tahap berkomunikasi atau berbagi informasi anak begitu antusias dan bergembira untuk mengikuti kegiatan tersebut

\section{DAFTAR PUSTAKA}

Adams-Chapman, I., Bann, C., Carter, S. L., \& Stoll, B. J. (2015). Language outcomes among ELBW infants in early childhood. Early Human Development, 91(6), 373-379. https://doi.org/10.1016/j.earlhumdev.2015.0 3.011

Aged, C. (2015). Bead Board Letter Media Effectiveness as The Introduction Concept of Reading in Children Aged 5-6 Years. Indonesian Journal of Early Childhood Education Studies, 4(1), 46-50. https://doi.org/10.15294/ijeces.v4i1.9453

Bornstein, M. H., Hahn, C. S., Putnick, D. L., \& Suwalsky, J. T. D. (2014). Stability of core language skill from early childhood to adolescence: A latent variable approach. Child Development, 85(4), 1346-1356. https://doi.org/10.1111/cdev.12192

Brown, C. (2014). Language and Literacy 
Development in the Early Years: Foundational Skills that Support Emergent Readers. Language and Literacy Spectrum, $24,35-49$.

Holod, A., Ogut, B., Brodziak de los Reyes, I., Quick, H. E., \& Manship, K. (2018). The effects of prekindergarten for Spanishspeaking dual language learners: Evidence from California's transitional kindergarten program. Early Childhood Research Quarterly. https://doi.org/10.1016/j.ecresq.2018.06.002

Ilhami, B. S., Fitri, B. F. H., \& Ramdhani, S. (2019). Permainan Kuda Bisik Untuk Meningkatkan Kemampuan Pembendaharaan Kosakata Anak Usia 5-6. Cakrawala Dini; Jurnal Pendidikan Anak Usia Dini, 10(2), 101-108.

Inten, D. N. (2017). Peran Keluarga dalam Menanamkan Literasi Dini pada Anak Role of the FamilyToward Early Literacy of the Children. Golden Age: Jurnal Pendidikan Anak Usia Dini, 1(1), 23-32. https://doi.org/10.29313/ga.v1i1.2689

Jalongo, M. R. (n.d.). E arly Childhood Language Arts.

Kemampuan, M., Dini, M., Kelompok, P., \& Jenggik, A. N. W. (2018). E-issn: 2549. 7367. 01(2), 75-81.

Kim, M. S. (2014). The multi-literacy development of a young trilingual child: Four leading literacy activities from birth to age six. European Early Childhood Education Research Journal, 22(2), 154-168. https://doi.org/10.1080/1350293X.2014.883 718

Madra, I. N. (2019). Improving Speaking Skill Through Inside-Outside Circle Technique of the Tenth Grade Students of Sma N 8 Denpasar. Yavana Bhasha: Journal of English Language Education, 1(2), 85-97. https://doi.org/10.25078/yb.v1i2.729

Marceillina, D. N., Wiryokusumo, I., \& Walujo, D. A. (2019). The Use of Probing Prompting Learning (PPL) and Inside Outside Circle (IOC) Model to Learning Outcome of Plane Figure Material. International Journal of Educational Technology and Learning, 5(1), 9-14. https://doi.org/10.20448/2003.51.9.14

Marsh, J. (2008). Media literacy in the early years. In Desirable Literacies: Approaches to Language and Literacy in the Early Years, Second

Edition. https://doi.org/10.4135/9781446279519.n11

Model, P., Induktif, P., Untuk, B., Kemampuan, P., \& Dini, L. (2016). Pengembangan Model Pembelajaran Induktif Kata Bergambar Untuk Pengenalan Kemampuan Literasi Dini Aud. Journal of Primary Education, 5(2), 120-129.

Muyaroah, S. (2018). Efektifitas Model Pembelajaran Inside Outside Cirle Terhadap Hasil Belajar Siswa Pada Mata Pelajaran Ipa Sd Fransiskus Baturaja. Pedagogia, 16(2), 99.

https://doi.org/10.17509/pdgia.v16i2.12052

Nafiah, A. C. (2016). Peningkatan Kemampuan Membaca Permulaan Melalui Metode Sctamble Kalimat Siswa Kelas II SDN Sedayu.

Nahdi, K., \& Yunitasari, D. (2019). Inside-outside circle: An early childhood language and literacy development method. International Journal of Innovation, Creativity and Change, 5(6), 325-335.

Nahdi, K., \& Yunitasari, D. (2020). Jurnal Obsesi : Jurnal Pendidikan Anak Usia Dini Literasi Berbahasa Indonesia Usia Prasekolah: Ancangan Metode Dia Tampan dalam Membaca Permulaan Abstrak. 4(1), 434-441.

https://doi.org/10.31004/obsesi.v4i1.372

Novitasari, K. (2019). Penggunaan Teknologi Multimedia Pada Pembelajaran Literasi Anak Usia Dini. Jurnal Golden Age, 3(01), 50-56.

Nuraeni, A. (2016). Peran Orang Tua dalam Pengembangan Literasi Dini Anak Kelompok B di Gugus 7 Mangunan Dlingo Bantul. Jurnal Pendidikan Anak Usia Dini, 3, 245-256. http://journal.student.uny.ac.id/ojs/index.php /pgpaud/article/viewFile/1256/1131

Palupi, Y., \& Pendahuluan, I. (2015). Perkembangan Bahasa Pada Anak. Wardah, 14(1), 25-33.

Paramita, M. V. A., \& Sutapa, P. (2019). Pengembangan Model Pembelajaran Berbasis Permainan Sirkuit Untuk Meningkatkan Motorik Halus Anak Usia 4-5 Tahun. Jurnal Golden Age, 3(01), 1-15.

Pertiwi, A. D., Universitas, P., \& Yogyakarta, N. (2017). Study Deskriptif Proses Membaca Permulaan Anak Usia Dini. Jurnal Pendidikan Anak, 5(1), 759-764. 
P ISSN 2548-6284 E ISSN 2615-0360

Vol. 4 No. 2 Juni 2020

Ramdhani, S., Alfian, M., \& Nurmayani, E. (2019). Mengembangkan Keterampilan Guru PAUD melalui Pelatihan Penulisan Dongeng dan Teknik Penyajian. Jurnal Pelita PAUD, 4(1), 49-56.

Ramdhani, S., Yuliastri, N. A., Sari, S. D., \& Hasriah, S. (2019). Penanaman Nilai-Nilai Karakter melalui Kegiatan Storytelling dengan Menggunakan Cerita Rakyat Sasak pada Anak Usia Dini. Jurnal Obsesi : Jurnal Pendidikan Anak Usia Dini, 3(1), 153. https://doi.org/10.31004/obsesi.v3i1.108

Ramírez, N. F., Lieberman, A. M., \& Mayberry, R. I. (2013). The initial stages of first-language acquisition begun in adolescence: When late looks early. Journal of Child Language, 40(2), $391-414$. https://doi.org/10.1017/S0305000911000535

Sudrajad, M., \& Wijaya, A. (2016). the Effectiveness of Inside-Outside Circle Method By Using Cue Card for Students' Speaking Ability At Seventh Graders. Journal of English Educators Society, 1(1), 59-70.

https://doi.org/10.21070/jees.v1i1.146

Sumaryanti, L. (2018). Membudayakan Literasi Pada Anak Usia Dini Dengan Metode Mendongeng. AL-ASASIYYA: Journal Of Basic Education, 3(1), 117. https://doi.org/10.24269/ajbe.v3i1.1332

Syahrum, \& Salim. (20

12). METODOLOGI KUANTITATIF.pdf (p. 184).

PENELITIAN

Toki, E. I., \& Pange, J. (2014). Ict Use in Early Childhood Education: Storytelling. Tiltai, 66(1), 183-192. https://doi.org/10.15181/tbb.v66i1.786

Valdebenito, S., Ttofi, M. M., Eisner, M., \& Gaffney, H. (2017). Weapon carrying in and out of school among pure bullies, pure victims and bully-victims: A systematic review and meta-analysis of cross-sectional and longitudinal studies. Aggression and Violent Behavior, 33, 62-77. https://doi.org/10.1016/j.avb.2017.01.004

Wijaya, S. (2017). Inside Outside Circle: Teaching Students' Speaking Skill. ELT Echo: The Journal of English Language Teaching in Foreign Language Context, 2(2), 114. https://doi.org/10.24235/eltecho.v2i2.2171 